\title{
Improvement the Production of Red Roomy Grapevines under Warm Climatic Conditions
}

\author{
Abou-zaid, Eman A.A. and Ebtsam F.M. Badawy \\ Pomplogy Department, Fac. Agric., Assiut University \\ E- mail: eman.hakeem@aun.edu.eg
}

Received on: 5/12/2018

Accepted for publication on: 17/12/2018

\section{Abstract}

This experiment was carried out at the Experimental station of the faculty of Agriculture, Assiut University during two successive seasons 2016/2017 on Red Roomy grapevines. The beneficial effects of spraying Dormex at $4 \%$, Salicylic acid at 5\%, Garlic oil at $2 \%$, camphor oil at $2 \%$ and Lemon grass oil at $2 \%$ on bud break and improve the Red Roomy production under warm climate were investigated. The experiment was arranged in a complete randomized design with three replicates per treatment, one vine per each. The results indicated that all treatments were very effective on breaking bud dormancy and improving the yield and quality of the berries compared with the check treatments. The best results regarding the improvement of cluster compactness coefficient, number of berries and berry setting were obtained with spraying lemon grass oil at $2 \%$ and camphor oil at $2 \%$. No significant differences were found between Dormax and the other compounds.

It could be concluded that using plant extracts i.e lemon grass oil, camphor oil and garlic oil as natural and safety substances were very effective to break bud dormancy and improve the grapevines fruiting.

Keywords: Red Roomy, natural products, break dormancy, Dormex, salicylic acid

\section{Introduction}

Grapes are one of the most important fruit crops for local consumption and export. It is considered as one of the most popular and favorite fruits in the world, because of an excellent flavor, nice taste and high nutritional value. The total world area of grapevines reached 10.5 million ha with a total production of 89 million ton fruits per year (F.A.O. 2015). Red Roomy is considered one of the most important seeded grape varieties grown in Egypt. The biggest problem faced the producers of Red Roomy grape cultivar in Assiut governorate is the delay and irregular bud break. Delaying and irregularity of bud break led to lower fruit set than expected due to occurrence at very high temperature during May (El- Sese and Mohamed 2003). Delaying and irregularity of bud break in numerous deciduous fruit crops are due to insufficient chilling hours necessary for complete bud break and terminate bud dormancy (Sparks, 1993, El-sese and Mohamed, 2003). Under warm conditions, there is a great need for artificial means to compensate the lake of natural chilling requirements to gain an economic production of dessert grapes (Or et al. 2000 and EL-Salhy 2002). Dormex (hydrogen Cyanamid) and the related compounds containing cyanamid has been widely used for terminating bud dormancy hasting, improving and regulating bud burst as well as increasing yield and improving berry quality in 
different grapevine cultivars (Omran 2000, EL-Salhy 2002 and Ben Mohamed et al. 2012). Dormex is a toxic and expensive compound, so it is necessary to replace it with new natural agents. Such agents must be easily available, effective and not toxic for human and plant. Plant extracts as natural products were used for improving growth, nutritional status and as pesticides for maintenance public health and environmental safety. Plant extracts containing phenolic compounds and other chemical constituents have synergistic effects on growth and fruiting of fruit trees. It can be used as natural and safety substances for breaking bud dormancy (Paik and Chung. 1997 and Srivestava and Lal, 1997 and Ahmed et al. 2014). Maldonado et al. (2010) examined the effect of garlic compounds on bud break dormancy and cluster quality in four table grape cultivars. They reported that Cluster weight and berry size of table grapevine cultivars were largest with best quality due to use garlic compound. Lemon grass oil is the essential oil obtained from the aerial parts of cymbopogon citrates, this plant has been widely recognized for its ethno botanical and medicinal usefulness (Oyedele et al. 2002). Gouda (2016) concluded that spraying lemon grass oil twice at $1 \%$ improved the production of Ruby Seedless grapevines. Salicylic acid is an endogenous plant growth regulator with phenolic nature and classified as a growth promoter .Moreover, it enhanced plant vigor under biotic and abiotic stresses. It has an important role in reducing the activity of catalase and increasing the release of $\mathrm{H}_{2} \mathrm{O}_{2}$ (Srivastava and
Dwivedi 2000, Zhang et al. 2003 and Hayat et al. 2010). Salicylic is a new plant hormone and has been shown to interfere with the biosynthesis and action of ethylene, ABA, and cytokinens. As well as, it can inhibit the abiotic stresses (Joseph et al. 2010 and Hayat et al. 2010) and has many important regulatory effects such as enhancing growth, yield and quality of berries in different grapevine cultivars (El-Hanafy 2011 and Mohamed Ebtesam 2012).

The present study aimed to study the effect of some plant extracts vs hydrogen cyanamid on breaking bud dormancy and improving productivity of Red Roomy grapevines growing under warm climates.

\section{Materials and Methods}

This study was carried out during 2016 and 2017 seasons on eighteen uniform Red Roomy grapevines. Vines were 25 years old at the beginning of experiment and spaced at $2 \times 2.5 \mathrm{~m}$ apart. The vines were grown at the Experimental orchard of the Faculty of Agriculture, Assiut University, Egypt. Head pruning system was applied by leaving a total bud load of 72 buds /vine for all the selected vines on the basis of 15 fruiting spurs $\mathrm{x} 4$ buds plus 6 replacement spurs $\mathrm{x} 2$ buds/vine. The chosen vines were received the usual horticultural practices which are used in the vineyard. The experiment was arranged in a complete randomized design with three replicates per treatment, one vine per each.

The experiment contained six treatments as follow: 
1. Spraying with Dormex at $4 \%$ ( $2 \%$ hydrogen cyanamid)

2. Spraying with camphor oil at $2 \%$

3. Spraying with lemon grass oil at $2 \%$

4. Spraying with garlic oil at $2 \%$

5. Spraying with salicylic acid at $5 \%$

6. Control (spraying with water)

The selected vines were sprayed during the first week of February in both seasons. Salicylic acid was dissolved in a few drops of ethyl alcohol. Another compounds were prepared by dissolving the assigned amounts in the required quantities of water. All vines were sprayed until the run - off point. Triton $\mathrm{B}$ at $0.1 \%$ as a wetting agent was used

The following measurements were recorded during the both seasons of study.

\section{1-Date of bud burst and its per- centage:}

Date of bud burst was recorded and then the number of burst buds/vine was recorded. The percentages of bud burst were calculated by dividing the number of burst bud /vine by total number of buds per vine at weekly interval along the bursting period.

\section{2- Fruiting buds\%.}

The fruiting buds $\%$ were calculated by dividing the number of fruity buds numbers by total number of buds/vine.

\section{3- Vegetative growth parameters:} a- Average leaf area $\left(\mathrm{cm}^{2}\right)$.

Average leaf area was estimated by weighting ten mature leaves/ vine and weighting 40 sections of $1 \mathrm{~cm}^{2}$ (4 sec. of $1 \mathrm{~cm}^{2} /$ leaf), then the leaf area $\left(\mathrm{cm}^{2)}\right.$ was estimated according to the equation:
Leaf area $\mathrm{cm}^{2}=\frac{\text { leaves weight }(\mathrm{g}) \mathrm{x} \text { section area }(\mathrm{cm} 2)}{\text { section weight }(\mathrm{gm})}$

b- Weight of pruning wood:

Weights of pruning wood were calculated immediately after pruning (January, 15) and expressed as g/vine.

\section{4- Yield components:}

Berry set percentage was estimated by caging five flower clusters on each vine in perforated paper bags before bloom. After berry set the bags were removed and the percentage of berry set was calculated as follows:

Berry set $\%=$ No. of berries/cluster $\mathrm{x}$ $100 /$ total of flowers/cluster

At harvest date the following parameters were recorded: number of cluster/vine, average cluster weight and total yield as $\mathrm{kg} /$ vine.

\section{5- Fruit quality:}

Cluster length, weight of 100 berries, number of berries/cluster and cluster compactness coefficient were determined according to Winkler et al. (1974). Berry chemical quality in terms of total soluble solids (T.S.S) was measured using hand refracto meter, reducing sugars percentage were determined as outline in A.O.A.C (1985), and titrtable acidity (TA) was determined by direct titration with $0.1 \mathrm{~N} \mathrm{NaOH}$ using phenolphthalein as an indicator and expressed as mg tartaric acid per $100 \mathrm{ml}$ juice according to A.O.A.C (1985). Total anthocyanin (mg/100 ml juice) using Ethyl alcohol and HCL at 85:15 and the optical density was determined using spectrophotometer at wave length 532 Markham (1982). 


\section{Statistical analysis}

The obtained data was subjected to the analysis of variances according to (Senedecor and Cochran 1990). LSD at 5\% level was used to compare the differences between the treatment means

\section{Results}

\section{1- Environmental Condition:}

Data in Table (1) showed the average of monthly temperatures in the experimental location during the two seasons of this study. The mean monthly temperature ranged from $15.25 \& 14.38^{\circ} \mathrm{C}$ in December to $19.80 \& 18.91{ }^{\circ} \mathrm{C}$ in March, which is insufficient for winter chilling to overcome dormancy. In this regard, Weaver (1976) showed that grapes usually require a winter indo dormancy of about 2 months, with an average daily mean temperature below $\left(10^{\circ} \mathrm{C}\right)$.

Table 1. Monthly Weather, Maximum, minimum and mean of temperature of $2015 / 2016$ and $2016 / 2017$ seasons

\begin{tabular}{|l|c|c|c|c|c|c|}
\hline \multirow{2}{*}{} & \multicolumn{3}{|c|}{$\mathbf{2 0 1 5 / 2 0 1 6}$} & \multicolumn{3}{c|}{$\mathbf{2 0 1 6 / 2 0 1 7}$} \\
\cline { 2 - 7 } & \multicolumn{3}{|c|}{ Temperature $\left({ }^{\circ} \mathbf{C}\right)$} & \multicolumn{3}{c|}{ Temperature( $\left.{ }^{\circ} \mathbf{C}\right)$} \\
\cline { 2 - 7 } & Max. & Min. & Mean & Max. & Min. & Mean \\
\hline Nov. & 28.00 & 13.40 & 20.70 & 28.83 & 12.80 & 20.82 \\
\hline Dec. & 23.10 & 7.40 & 15.25 & 21.90 & 6.86 & 14.38 \\
\hline Jan. & 23.80 & 8.00 & 15.90 & 20.99 & 4.96 & 12.98 \\
\hline Feb. & 26.20 & 7.00 & 16.60 & 22.97 & 5.39 & 14.18 \\
\hline Mar. & 26.20 & 13.40 & 19.80 & 27.08 & 10.73 & 18.91 \\
\hline Apr. & 33.40 & 12.40 & 22.90 & 33.22 & 14.39 & 23.81 \\
\hline
\end{tabular}

After, Assiut Weather station.

\section{2- Effect of treatments on bud be- havior}

Results in Table (2) showed the effect of treatment on bud burst \%, fruiting bud $\%$ and date of bud burst of Red Roomy grapevines in 2016 and 2017 seasons. The results took the similar trend during the two studied seasons. All treatments significantly increased the percentage of bud burst and fruiting buds as well as the advancement of they advanced bud burst and blooming over the check treatments. The highest bud burst percentages $(88.89 \%)$ as an average of the two studied seasons were recorded on the vines that received Dormex at $4 \%$, followed by lemon grass oil at $2 \%(87.5 \%)$. The fruiting buds percentage were 45.85 \&
$44.70 \%$ as an average. Of the two studied seasons due to garlic oil at $2 \%$ and salicylic acid at 5\%, respectively. Dormex at $4 \%$ exhibited the early date of bud burst (11 Mar) followed by garlic oil at 2\% (12 Mar) as an average of the two studied seasons. On the other hand, untreated vines recorded the lowest values of such traits (bud burst $54.86 \%$ ), fruiting buds $(27.07 \%)$ and the date of bud burst (30 Mar) as an average of the two studied seasons. The early days of bud burst compared to control were 19, 8, 12, 18 and 11days (as an average of the two studied seasons) for Dormex, camphor oil, lemon grass oil, garlic oil and salicylic acid, respectively. The corresponding increment percentage of bud burst $\%$ 
and fruiting buds\% for the above mentioned treatments over the control were $59.30,55.67,59.50,58.24$ and $51.87 \%$ and 54.19, 52.60, 53.27, 64.57 and $65.13 \%$ as an average. Of the two studied seasons, respectively. No significant differences were found among treatments regarding bud burst and fruiting bud percentage.

\section{3- Effect of treatments on vegeta- tive growth.}

Table (2) exhibits the effect of studied treatments on some growth characteristics. Data showed that all used compounds significantly increased the leaf area and pruning weight over the check treatments. The maximum values of leaf area were recorded on the vines that received Dormex at $4 \%\left(180.44 \mathrm{~cm}^{2}\right)$ followed by camphor oil at $2 \%$ $\left(180.18 \mathrm{~cm}^{2}\right)$ as an average of two studied seasons. Meanwhile, the maximum values of pruning weight were noticed due to spray garlic oil and camphor oil at $2 \%(1.57$ and $1.55 \mathrm{~kg}$ as an average, of the two studied seasons), respectively. The untreated vines gave the lowest values of their leaf area and pruning wood weight due spray garlic oil and camphor oil at $2 \%$. No significant differences were found due to use any plant oils compared to Dormex during the two studied seasons.

\section{4- Effect of treatments on yield components:}

It is evident from the data in Table(3) that spraying Dormex, salicylic acid and natural oils significantly increased the berry set $\%$ number of clusters/ vine and yield/vine compared to unsprayed ones in both seasons. Salicylic acid, garlic oil and lemon grass oil were the most effective in this concern compared to the other treatments. No significant differences were detected among salicylic acid, garlic oil and lemon grass oil. The heaviest yield was recorded on vines that sprayed with salicylic acid at $5 \%(13.41 \mathrm{~kg} / \mathrm{vine})$ and lemon grass oil at $2 \%(13.05 \mathrm{~kg} / \mathrm{vine}$ as an average of two studied seasons). The untreated vines produced the lowest yield $(6.29 \mathrm{~kg} /$ vine as an average of two studied seasons). Hence, the increment percentage of yield / vine over untreated ones were attained $78.22,86.80,107.47,104.77$ and $113.20 \%$ as an average of the two studied seasons due to spray Dormex, camphor oil, lemon grass oil, garlic oil and salicylic acid, respectively.

Table 2. Effect of Dormex, some plant oils and salicylic acid on bud burst\%, fruiting buds\%, date of bud burst, earliest/day leaf area $\left(\mathrm{cm}^{2}\right)$ and pruning weight (kg) of Red Roomy grapevines during 2016 and 2017 seasons.

\begin{tabular}{|c|c|c|c|c|c|c|c|c|c|c|c|c|c|c|c|c|}
\hline \multirow{2}{*}{$\begin{array}{c}\text { Treatment } \\
\text { No. }\end{array}$} & \multicolumn{3}{|c|}{ Bud burst $\%$} & \multicolumn{3}{|c|}{ Fruiting buds $\%$} & \multicolumn{4}{|c|}{ Date of bud burst } & \multicolumn{3}{|c|}{$\begin{array}{c}\begin{array}{c}\text { Leaf area } \\
\left(\mathrm{cm}^{2}\right)\end{array} \\
\end{array}$} & \multicolumn{3}{|c|}{$\begin{array}{c}\text { Pruning weight } \\
\text { (kg) }\end{array}$} \\
\hline & 2016 & 2017 & an & 16 & 2017 & Mean & 16 & \begin{tabular}{|c|}
$\begin{array}{c}\text { Earli- } \\
\text { ness/day }\end{array}$ \\
\end{tabular} & & \begin{tabular}{|c|} 
Earli- \\
ness/day \\
\end{tabular} & 116 & 2017 & Mean & |201 & 2017 & Mean \\
\hline & 86 & & & & & & 12 & & & 2 & & & & & & \\
\hline & & & & & & & $24 / 1$ & & & & & & & & & \\
\hline & & & & & 43 & & 20 & & & & 176.5 & & & 1 & & .53 \\
\hline & & & 88 & 43 & & 34 & $9 / \mathrm{M}$ & & & & 76.68 & & 17 & 1. & & 1.57 \\
\hline 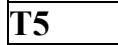 & 81.90 & 84.63 & 8. & 44.17 & 745.22 & 244.70 & $20 / \mathrm{Mar}$ & 10 & $18 / \mathrm{Mar}$ & 11 & 174.80 & 178.10 & 17 & 1.47 & 1 & 52 \\
\hline 16 & 52.78 & 856.94 & 454.86 & 25.94 & 428.19 & 27.07 & $30 / \mathrm{Mar}$ & -- & $29 / \mathrm{Mar}$ & -- & 159.84 & 163.18 & 161.51 & 1.21 & 1. & 1.25 \\
\hline & 4.11 & 4.65 & & 3.25 & 3.66 & & & & & & 6.48 & \begin{tabular}{|l|l}
7.60 \\
\end{tabular} & & \begin{tabular}{|l|} 
\\
\end{tabular} & 0.0 & \\
\hline
\end{tabular}


Table 3. Effect of Dormex, some plant oils and salicylic acid on berry setting\%, number of clusters/vine and yield/vine (kg) of Red Roomy grapevines during 2016 and 2017 seasons.

\begin{tabular}{|l|c|c|c|c|c|c|c|c|c|}
\hline \multirow{2}{*}{$\begin{array}{c}\text { Treatment } \\
\text { No. }\end{array}$} & \multicolumn{3}{|c|}{ Berry setting\% } & \multicolumn{3}{c|}{ Number of clusters/ vine } & \multicolumn{3}{c|}{ Yield/Vine (kg) } \\
\cline { 2 - 10 } & $\mathbf{2 0 1 6}$ & $\mathbf{2 0 1 7}$ & Mean & $\mathbf{2 0 1 6}$ & $\mathbf{2 0 1 7}$ & Mean & $\mathbf{2 0 1 6}$ & $\mathbf{2 0 1 7}$ & Mean \\
\hline T1 & 9.69 & 10.18 & 9.94 & 26.33 & 30.33 & 28.33 & 10.35 & 12.07 & 11.21 \\
\hline T2 & 10.18 & 10.98 & 10.58 & 26.13 & 28.63 & 27.38 & 11.11 & 12.40 & 11.75 \\
\hline T3 & 10.11 & 10.85 & 10.48 & 27.50 & 30.30 & 28.90 & 12.23 & 13.87 & 13.05 \\
\hline T4 & 9.87 & 9.99 & 9.93 & 29.80 & 32.66 & 31.23 & 12.13 & 13.65 & 12.89 \\
\hline T5 & 9.75 & 10.63 & 10.19 & 29.50 & 31.70 & 30.60 & 12.83 & 13.98 & 13.41 \\
\hline T6 & 7.42 & 8.18 & 7.8 & 18.68 & 20.30 & 19.49 & 6.10 & 6.48 & 6.29 \\
\hline L.S.D at 5\% & 0.58 & 0.66 & & 1.34 & 1.86 & & 0.68 & 0.73 & \\
\hline
\end{tabular}

$\mathrm{T} 1=$ Dormex , T2= Camphor oil, T3= Lemon grass oil, T4= Garlic oil, T5= salicylic acid, T6= Control

\section{5-Effect of treatments on cluster and berry attributes:}

Data presented in Table (4) show the effect of Dormex at $4 \%$, camphor oil at $2 \%$, lemon grass oil at $2 \%$, garlic oil at $2 \%$ and salicylic acid at $5 \%$ on cluster weight, number of berries/cluster, cluster length, compactness coefficient and berry weight of Red Roomy grapevines during 2016 and 2017 seasons. Generally, data indicated that all spraying treatments significantly increased these traits compared to the control. The maximum value of cluster weight $(450.15 \mathrm{~g})$, number of berries (105.95) and compactness coefficient $(4.16 \%)$ (as an average of the two studied seasons) were recorded due to spray with lemon grass oil, whereas, camphor oil gave the maximum value of cluster length $(26.10 \mathrm{~cm}$ as an average of the two studied seasons). Moreover salicylic acid gave the highest value of berry weight $(3.62 \mathrm{~g}$ as an average of the two studied seasons). In the contrary; the control treatment gave the minimum values of all the studied cluster traits. The increment percentage of cluster weight and compactness coefficient were $37.75 \& 17.51 \%$ (as an average of the two studied seasons) due to spray lemon grass oil compared to unsprayed vines.

Data presented in Tables (4\&5) indicated that spraying Dormex, salicylic acid and natural oils significantly improved the berry quality in terms of increasing berry weight, reducing sugars $\%$, T.S.S $\%$ as well as berry anthocyanin content and decreasing total acidity $\%$ compared to check treatment. The maximum values of berry weight (3.62g), T.S.S (19.17\%) and anthocyanin (1.78 $\mathrm{mg} / \mathrm{g} \mathrm{fw})$ as an average of the two studied seasons was noticed with spray salicylic acid at 5\%, meanwhile the highest value of reducing sugars $(16.29 \%)$ as an average of the two studied season was recorded due to spray with Dormex at 4\%. On the other hand, the least value of total acidity $(0.337 \%)$ (as an average of the two studied seasons) was recorded when the vines were sprayed with salicylic acid followed by Dormex $(0.339 \%)$. The lowest values of berry weight, anthocyanin, reducing sugars and T.S.S $(3.16,0.70 \& 13.66$ and $15.50 \%$ as an average of the two studied seasons) were recorded on untreated vines which also gave the highest value of total acidity $\%(0.497 \%$ as an average of the two studied seasons). Hence the incensement percentage of berry weight due to such treatments over the untreated ones was 11.39, 10.13, 12.66, 12.97 and $14.55 \%$ due to use Dormex, camphor oil, lemon grass oil garlic oil and salicylic acid, respectively. 
Table 4. Effect of Dormex, some plant oils and salicylic acid on cluster weight (g), number of berries, cluster length $(\mathrm{cm})$ and compactness coefficient of Red Roomy grapevines during 2016 and 2017 seasons.

\begin{tabular}{|c|c|c|c|c|c|c|c|c|c|c|c|c|c|c|c|}
\hline \multirow{2}{*}{$\begin{array}{l}\text { Treatment } \\
\text { No. }\end{array}$} & \multicolumn{3}{|c|}{$\begin{array}{c}\text { Cluster weight } \\
\text { (g) }\end{array}$} & \multicolumn{3}{|c|}{$\begin{array}{c}\text { Number of } \\
\text { berries }\end{array}$} & \multicolumn{3}{|c|}{$\begin{array}{c}\begin{array}{c}\text { Cluster length } \\
\text { (cm) }\end{array} \\
\end{array}$} & \multicolumn{3}{|c|}{$\begin{array}{c}\text { Compactness } \\
\text { coefficient }\end{array}$} & \multicolumn{3}{|c|}{$\begin{array}{c}\text { Berry weight } \\
\text { (g) }\end{array}$} \\
\hline & 2016 & 2017 & Mean & 2016 & 2017 & Mean & 2016 & 2017 & Mean & 2016 & 2017 & Mean & 2016 & 2017 & Mean \\
\hline T1 & 393.30 & 398.50 & 395.90 & 100.80 & 101.50 & 101.15 & 25.30 & 26.40 & 25.85 & 3.98 & 3.85 & 3.92 & 3.41 & 3.63 & 3.52 \\
\hline $\mathrm{T} 2$ & 425.50 & 433.30 & 429.40 & 104.30 & 108.70 & 106.50 & 26.00 & 26.20 & 26.10 & 4.01 & 4.30 & 4.16 & 3.40 & 3.56 & 3.48 \\
\hline T3 & 445.00 & 455.30 & 450.15 & 104.60 & 107.30 & 105.95 & 24.70 & 26.30 & 25.50 & 4.24 & 4.08 & 4.16 & 3.67 & 3.67 & 3.56 \\
\hline T4 & 407.30 & 418.40 & 412.85 & 100.80 & 102.20 & 101.50 & 25.40 & 26.30 & 25.85 & 3.97 & 3.89 & 3.93 & 3.51 & 3.63 & 3.57 \\
\hline T5 & 435.70 & 441.50 & 438.60 & 100.20 & 104.80 & 102.50 & 25.0 & 26.4 & 25.70 & 4.01 & 3.97 & 3.99 & 3.46 & 3.78 & 3.62 \\
\hline T6 & 325.80 & 318.40 & 322.10 & 85.80 & 89.30 & 87.55 & 24.6 & 23.8 & 24.20 & 3.36 & 3.71 & 3.54 & 3.08 & 3.28 & 3.16 \\
\hline L.S.D at $5 \%$ & 16.13 & 19.81 & & 3.96 & 3.58 & & 0.93 & 1.18 & & 0.16 & 0.21 & & 0.21 & 0.26 & \\
\hline
\end{tabular}

$\mathrm{T} 1=$ Dormex, $\mathrm{T} 2=$ Camphor oil, $\mathrm{T} 3=$ Lemon grass oil, $\mathrm{T} 4=$ Garlic oil, $\mathrm{T} 5=$ salicylic acid, $\mathrm{T} 6=$ Control

Table 5. Effect of Dormex, some plant oils and salicylic acid on reducing sugars\%, anthocyanin $\mathrm{mg} / \mathrm{g}$, T.S.S\% and acidity\% of Red Roomy grapevines during 2016 and 2017 seasons.

\begin{tabular}{|c|c|c|c|c|c|c|c|c|c|c|c|c|}
\hline \multirow{2}{*}{$\begin{array}{l}\text { Treatment } \\
\text { No. }\end{array}$} & \multicolumn{3}{|c|}{ Reducing sugars\% } & \multicolumn{3}{|c|}{ Anthocyanin mg/g } & \multicolumn{3}{|c|}{ T.S.S\% } & \multicolumn{3}{|c|}{ Acidity\% } \\
\hline & 2016 & 2017 & Mean & 2016 & 2017 & Mean & 2016 & 2017 & Mean & 2016 & 2017 & Mean \\
\hline T1 & 15.86 & 16.73 & 16.29 & 1.74 & 1.77 & 1.76 & 18.67 & 19.50 & 19.09 & 0.396 & 0.283 & 0.339 \\
\hline $\mathbf{T 2}$ & 16.25 & 15.87 & 16.06 & 1.66 & 1.69 & 1.68 & 19.00 & 18.25 & 18.63 & 0.386 & 0.303 & 0.345 \\
\hline T3 & 15.88 & 16.17 & 16.03 & 1.67 & 1.72 & 1.70 & 18.85 & 19.18 & 19.02 & 0.373 & 0.330 & 0.352 \\
\hline T4 & 15.53 & 16.32 & 15.93 & 1.66 & 1.72 & 1.69 & 18.20 & 19.67 & 18.94 & 0.366 & 0.317 & 0.342 \\
\hline T5 & 16.11 & 16.36 & 16.24 & 1.75 & 1.80 & 1.78 & 19.00 & 19.33 & 19.17 & 0.332 & 0.341 & 0.337 \\
\hline T6 & 13.47 & 13.85 & 13.66 & 0.68 & 0.72 & 0.70 & 15.33 & 15.67 & 15.50 & 0.543 & 0.450 & 0.497 \\
\hline L.S.D at 5\% & 0.87 & 1.10 & & 0.11 & 0.09 & & 0.51 & 0.48 & & 0.013 & 0.018 & \\
\hline
\end{tabular}

$\mathrm{T} 1=$ Dormex, $\mathrm{T} 2=$ Camphor oil, $\mathrm{T} 3=$ Lemon grass oil, $\mathrm{T} 4=$ Garlic oil, $\mathrm{T} 5=$ salicylic acid, $\mathrm{T} 6=$ Control

\section{Discussion}

Dormex had apositive action on breaking dormancy and improving vegetative growth and fruit quality of Red Roomy grapevines due to its effect on removing buds scales, reducing $\mathrm{ABA}$, catalase, reduced and oxidized glutathione and enhancing free water, IAA, $\mathrm{GA}_{3}$, cytokines, soluble sugars, amino acids, total indoles, oxidative stress, $\mathrm{H}_{2} \mathrm{O}_{2}$, total free polyamines and enzymes activities (Rady and seif- El yazel, 2013 and Mohamed and Goud 2017). Spraying camphor oil advanced bud burst, floral buds and enhanced floral buds of Flame seedless and Thompson Seedless grapevines (Mustafa et al. 2015). The positive action of garlic oil on breaking bud dormancy in grapevines may be due to its contents of sulfur containing compounds (ally group and mono- di tri and tetra sulfides), volatiles, tannins, phenols antioxidants, vitamins and amino acids and cysteine, such compounds act as a processor for the synthesis of garlic oil containing reduced sulphur as well as for other biosynthesis pathways such as the formation of ethylene. Lemon grass oil is mainly comprised of monoterpenes compound like citral (65- $80 \%)$, citral $(3,7$ - dimethyl 2,6 - octadienal) is a mixture of monoterpene aldehydes, isomers neral and geranial. The other important functional components include limonene, citronella, monoterpene olefins, such as a- myrcene, and alcoholic polar compound geraniol (Schaneberg $\&$ Khan 2002). It is used in the manufacture of synthetic vitamin volatils, phenols, antioxidants and plant pigments (Masamba et al. 2003). Sali- 
cylic acid enhancing $\mathrm{H}_{2} \mathrm{O}_{2}$ and natural hormone and reducing ethylene biosynthesis, such effects could explain the present results (Hayat et al. 2010). Moreover, Abd EL- Kareem (2009), EL- Kady - Hanaa (2011) and EL- Hanafy (2011) confirmed the present results concerning the positive action of salicylic acid on fruiting of grapevines. The obtaind results of this experiment are in line with those found by EL- Halaby (2009), Abdalla (2007), Mekawy (2008), ElSawy (2009), Biasia et al. (2010), Ahmed et al. (2014), Mostafa et al. (2015) and Mohamed and Gouda. (2017) who studied bud breaking and fruiting of grape.

\section{Conclusion}

Generally, it can be concluded that plant extracts such as lemon grass oil, camphor oil and garlic oil as natural and safety substance can be used instead of synthetic chemical for breaking Dormancy and improving yield and quality of Red Roomy grapevines growing under hot climate.

\section{References}

A.O.A.C. Association of official Agricultural chemists (1985). Official Methods of Analysis A.O.A.C. Benjamin franklin station, Washington, D.C.M.S.A. pp.440- 512.

Abd EL-Kareem, A.M.(2009). Relation of fruiting in Crimson Seedless grapevines to spraying antioxidants. M.Sc. Thesis Fac. Agri. Minia Univ. Egypt.

Abdallah, R.D. (2007). Effect of some rest breakages on bud development stages, vegetative growth and productivity of Flame seedless grapevines. Ph.D. thesis Fac. of Agri., Minia Uni. Egypt.

Ahmed, F.F., M.I.H. Ibrahim; M.A.M. Abada and M.M.M. Osman
(2014). Using plant extracts and chemical rest breakages for breaking and dormancy and improving productivity of Superior grapevines growing under hot climates. World Rual observation 6 (3): 818.

Ben Mohamed, H., Vadel, A.M.,Geuns, J.M.C., Khemira. H.,(2012). Carbohydrate changes during dormancy release in suberior seedless grapevine cuttings following hydrogen cyanamide treatment. Sci. Hortic. 140, 19- 25.

Biasia, L.A; Lipiski; Silva, E.D; Olivera, O.R; Sachi, A. Peressuiti, R.A. (2010). Lime Sulphur, mineral oil and garlic extract to suppress dormancy of Kiwi Revistade eterinarias 9- 58-68.

EL- Halaby, E.H.S.(2006). Trials for producing early with high quality "Superior grapes". M.Sc. Thesis Fac.of Agric. Minia Univ. Egypt.

EL- Hanafy, W.M.F.(2011). The role of some antioxidants on improving vines productivity in Red Roomy grapevine vineyard. M.Sc. Thesis Fac. of Agric. Minia Univ. Egypt.

EL-Kady- Hanaa, F.M. (2011). Performance of Thompson Seedless grapevine in relation to application of some antioxidants, magnesium and boron. M.Sc. Thesis fac. of Agric. Minia Uni. Egypt.

EL-Salhy, A.M.(2002). Improvement of bud burst, yield and berry quality of King's Ruby grapevines under warm climates by using dormex and ammonium nitrate spraying. Assiut J. Agric. Sci., 33(2):71-86.

EL- Sawy, Y.A.E.(2009). Attempts for breaking dormancy and improving fruting of Superior grapevine. Ph.D. Thesis fac. of Agric. Minia. Univ. Egypt.

EL-Sese, A.M. and A-M. Mohamed (2003). Chilling, heat requirements and hormonal control in relation to 
bud dormancy in Red Roomy and Thompson seedless grape cultivars (vitis vinifera L.). Assiut J. Agric. Sci., 34(6): 221-236.

Food and Agriculture Organization of the United Nations (FAO) 2015. Book Year.

Gouda- Fatima EL- Zahraa M. (2016). Effect of $\mathrm{GA}_{3}$ and Lemon grass oil spraying on fruiting of Ruby seedless grapevines. Assiut J. Agric. Sci., 47(6-1):173-180.

Hayat, Q.; Hayat, S.; Irtan, M. and Ahmed, A.(2010). Effect of exogenous Salicylic acid under changing environment. Areview Environ. Expel. Bot., 68:14-25.

Josephe, P.; Jini, D. and Sujatha, S. (2010). In sight in to the role of exogenous Salicylic acid in plants under environment. Asian J. of Crop. Sci. 2:226-235.

Maldonado, C.C., Tellez M.A.M., Gardea A.A., Avitia A.O. and Arispuro I.V.(2010). Organic alternative for breaking dormancy in table grapes grown in hot regions. Amer. J. of Agric. and Bio1. Sci., 5(2): 143- 147.

Markham, K.P.(1982). Technique of Flavonoids identification. Academic press, London.

Masamba, W.R.L., J.F.M., Kamanula, Elizabeth M.T. Henry and G.K.C., Nyirenda,(2003). Extraction and analysis of lemon grass (Cymbopogon citrates) oil an essential oil with potential to control the Larger Grain Borer (Prostephanus truncates) in stored products in Malawi. Malawi J. Agri. Sci., 2:56- 64.

Mekawy, A.Y. (2008). Attempts for breaking Endo dormancy in Red Roomy Grapevines. M.Sc. Thesis Fac. of Agric. Minia Uni. Egypt.

Metabolesim during floral bud break to onion extract. Scientia Hort. 15578-84.
Mohamed- Ebtesam, S.E.(2012). Response of Botany grapevine to some ethryl, nuterinet and antioxidant treatments. Ph.D. Thesis Fac. of Agric. Minia Uni. Egypt.

Mohamed, A.A. and Gouda, F.M.(2017). Effect of Dormex, Fructose and Methionine spraying on Bud Dormancy Release of "Superior" grapevines. Assiut J. Agric. Sci., (48) No.(2).

Mostafa, F.M.; A.K.A. Mohamed; Merfat A. Aly and M.K. Rizkalla (2015). Effect of Garlic and Camphor oils on Bud Fertility and yield components of Flame seedless Grape Cultivar. Assiut J. Agric. Sci., (46) No.(3) 100-119.

Omran, Y.A.M(2000). Studied on histophysiological effects of hydrogen Cyanamid (dormex) and yeast applications on bud fertility, vegetative growth and yield of "Romi Red" grape cultivar. Ph.D. Dissertation, Fac. Agric., Assiut Uni., $186 \mathrm{pp}$.

Or, E., E. Belausov, I.Popilevsky and Y.B. Tal (2000). Changesin endogenous $\mathrm{ABA}$ level in relation to the dormancy cycle in grapevines growth in a hot climate. J. of Hort. Sci. and Biotechnology 75(2):190194.

Oyedele, A.O., Gbolade, A.A., Sosan, M.B., Adewoyin, F.B., Soyelu, O.L, \& Oratidiya, O.O. (2002). Formulation of an effective inosquiro- repellent topical product from Lemon grass oil, phytomedicine, 9(3), 259- 262.

Paik, S. and I. Chung (1997). Effect of medicinal plant extracts on Apple storage disease. Korean J. of plant pathology, 13:57-62.

Poni, S.; I. Filippetti and A. Zanatti (1990). Effects of Dormex applications of vitis vinifera (cv. Sangiovese) in acold winter area. Advances in Hort. Sci., 4(2):121-126. 
Rady, M.M. and Seif EL-Yazal, M.A. (2013). Response of Anna apple dormant buds and carpohydrat metabolesim during floral bud break to onion extract. Scientia Hort. 155-78-84.

Schaneberg, B.T., \& Khan, I.A.(2002). Comparison of extraction methods for marker compounds in the essential oil of Lemon grass by Gc. Journal of Agricultural and chemistry, 50 (6), $1345-1349$.

Snedecor, G.W. and W.G. Cochran (1990). Statistical Methods $7^{\text {th }}$ Ed. The Iowa State Univ., Press.

Sparks, D.(1993). Chilling and heating model for pecan bud break. J. Amer. Soc. Hort. Sci. 118:29- 35.
Srivastava, A.K. and B.Lal (1997). Studies on bio fungicidal properties of leaf extract of some plants. Indian phytopath. 50 (3): 408-411.

Srivastava, K.M., U.N. Dwivedi (2000). Delayed ripening of banana fruit by Salicylic acid. Plant Sci,158:8796.

Weaver, R.J.(1976). Grape growing. Uni. Of Calif. Davis, pp. 106-174.

Winkler, A.J., J.A. Cook, W.M. Kliwer and L.A. Lider(1974). General virticulture. Published by university of California pren, B ashley.

Zhang, Y., C. Kunsong, S. Zhang, I. Ferguson. (2003). The role of Salicylic acid in postharvest ripening of Kiwi Fruit. Postharvest Biol. Tec., 28(1):67- 74. 
تحسين انتاجية شجيرات العنب الرومى الاحمر تحت ظروف المناخ الدافئ

ايمان عبد الحكيم عبد الله و ابتسام فتحى محمد الاعند

قسم الفاكهة - كلية الزر اعة - جامعة أسيوط

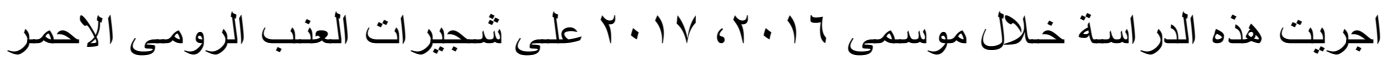

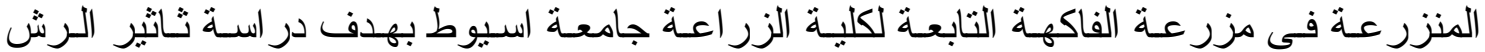

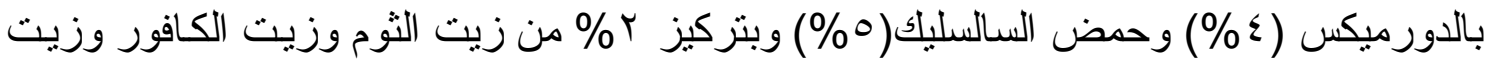

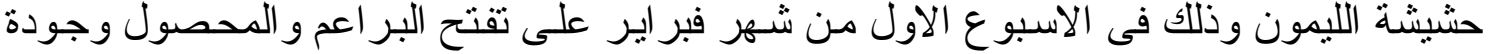
الثمار.

ولقد صـمدت التجربـة بتصميم قطاعـات كاملـة العشو ائية وثنلاث مكرر ات لكل معاملـة وشجيرة لكل مكررة

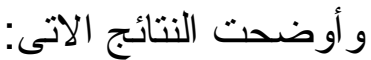

ـادت جميع المعاملات الى زيادة في نسبة تقتح البر اعم ونسبة البر اعم الثمريـة مـع التبكير

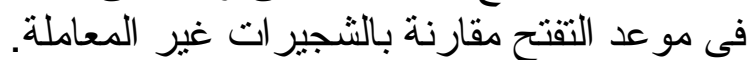

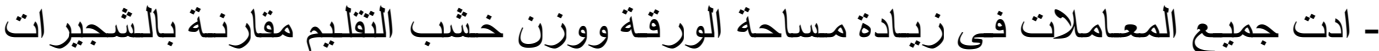

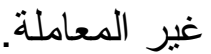

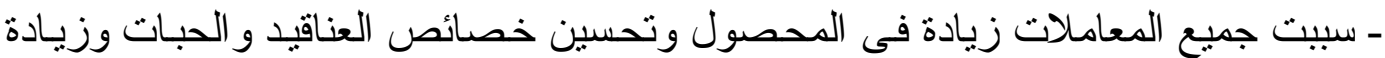

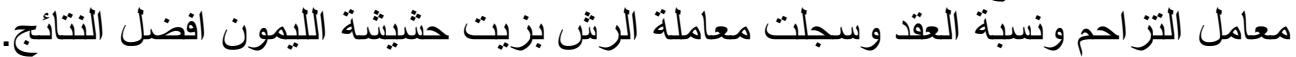

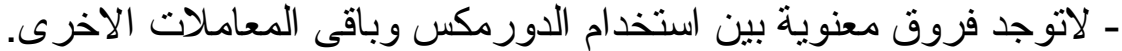

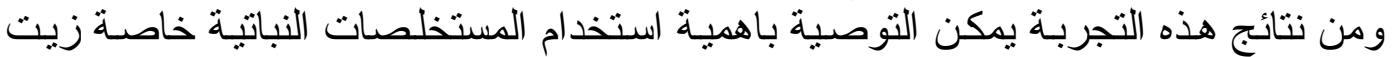

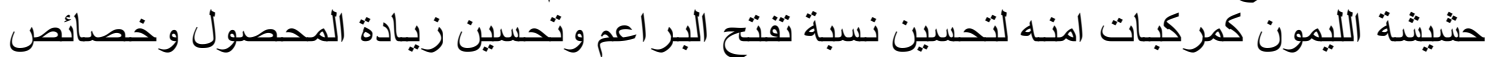

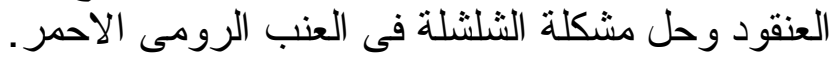

